\title{
Serum levels of CC16, SP-A and SP-B reflect tobacco-smoke exposure in asymptomatic subjects
}

\author{
M. Robin*, P. Dong", C. Hermans*, A. Bernard*, A.D. Bersten", I.R. Doyle ${ }^{\#}$
}

Serum levels of CC16, SP-A and SP-B reflect tobacco-smoke exposure in asymptomatic subjects. M. Robin, P. Dong, C. Hermans, A. Bernard, A.D. Bersten, I.R. Doyle. C ERS Journals Ltd 2002.

ABSTRACT: Since the 16-kDa bronchiolar Clara cell protein $(\mathrm{CC16})$ and the alveolar surfactant-associated proteins (SP)-A and -B leak into the circulation when parenchymal health is disturbed, the aim of this study was to determine whether their serum levels could serve as early peripheral markers of tobacco smoke-induced epithelial injury.

Sixty-nine (51 yrs (32-54) median (25-75th percentile)) nonsmokers and 54 (42 yrs (31-53)) asymptomatic smokers were enrolled in the study.

Serum levels of SP-A did not differ between subjects $(270$ (208-389) versus 259 $\left.(168-392) \mu \mathrm{g} \cdot \mathrm{L}^{-1}\right)$, however, CC16 levels decreased (10.6 (8.7-14.6) versus 7.6 $\left.(6.0-11.2) \mu \mathrm{g} \cdot \mathrm{L}^{-1}\right)$ and SP-B levels increased $(2,529(2,091-2,943)$ versus 3,053 $\left.(2,613-4,188) \mu \mathrm{g} \cdot \mathrm{L}^{-1}\right)$ in the smokers. When tobacco smoke exposure, serum creatinine (renal index), age and sex were used as independent variables, CC16 was negatively influenced by cumulative smoking and positively influenced by age. SP-A and -B were negatively influenced by creatinine and positively influenced by cumulative smoking. Serum SP-B was inversely correlated with forced expiratory volume in one second/vital capacity, suggesting an association between obstructive disease and parenchymal lung health.

The authors suggest that serum surfactant-associated proteins-A and -B reflect increased alveolocapillary leakage whereas Clara cell secretory protein 16 reflects tobacco smoke-induced Clara cell toxicity. Their evaluation may allow the effects of tobacco smoke on different levels of the respiratory tract, cellular toxicity and epithelial leakage to be distinguished.

Eur Respir J 2002; 20: 1152-1161.

Tobacco smoke exerts a variety of biological effects on the respiratory tract including adrenergic and cholinergic stimulation, ciliostasis, mucus hypersecretion, oxidative stress, inflammation and deoxyribonucleic acid damage that may be associated with increases in the incidence and severity of several diseases including cancer and chronic obstructive lung disease (COPD). Indeed, tobacco smoking is the major cause of emphysema. However, currently there are no biological markers sufficiently sensitive to assess parenchymal lung health before functional abnormalities become apparent.

The lung epithelium secretes several specific proteins into the airspaces of the respiratory tract. These include the 16-kDa bronchiolar Clara cell secretory protein $(\mathrm{CC} 16)$, the main secretory product of bronchiolar Clara cells, as well as surfactant-associated proteins (SP)-A and -B, secreted primarily by alveolar type II cells [1]. These proteins occur physiologically in small amounts in blood [2-4] and because they are secreted into the respiratory tract, their occurrence in serum can only be explained by leakage into the vascular compartment. Although the exact
*Industrial Toxicology and Occupational Medicine Unit, Faculty of Medicine, Catholic University of Louvain, Brussels, Belgium. ${ }^{\#}$ Depts of Human Physiology and Critical Care Medicine, School of Medicine, Flinders University, Adelaide, Australia.

Correspondence: I.R. Doyle, Dept of Human Physiology, Flinders University, Bedford Park, South Australia, Australia 5042 .

Fax: 61882045768

E-mail: Ian.Doyle@flinders.edu.au

Keywords: Alveolocapillary leakage, Clara cell secretory protein, Clara cell toxicity, surfactant protein-A, surfactant protein-B, tobacco smoke

Received: November 22001

Accepted after revision: June 122002

This work was supported by the National Fund for Scientific Research (FNRS), the Belgian Government Association (CT DD/MD006) and the European Commission (QLK 4-1308), the National Health and Medical Research Council of Australia and Autogen Research Pty Ltd. mechanisms by which these proteins enter the blood remains poorly understood, their concentrations in serum, referred to as pneumoproteinaemia [1], can be used to assess the leakage of the lung epithelial barrier and/or the integrity of the epithelial cells secreting them. Indeed, their intravascular leakage increases in conditions characterised by pulmonary inflammation and/or pulmonary epithelial injury [2, 4-8].

Tobacco smoking increases lung leakage, both acutely through smoke-induced release of vasoactive neuropeptides (tachykinins) from sensory nerves in the airways [9] and chronically through early destruction of connective tissue in the lung parenchyma. Consequently, monitoring pneumoproteinaemia may offer new possibilities in the assessment of lung injury caused by tobacco smoke. Others have reported previously that serum SP-A is elevated in smokers, although no relationship was observed with the amount of smoking $[10,11]$. However, the current authors have shown that SP-A is a relatively insensitive marker of parenchymal lung injury, presumably because of its size (native relative molecular mass $\left(M_{r}\right)$ $\sim 650 \mathrm{kDa})$ [2]. Although CC16 is much smaller, its 
circulating levels reflect both the integrity of lung epithelium and that of the Clara cells which secrete it. Indeed, it has been shown, by the current authors, that it is decreased both in bronchoalveolar lavage fluid [3] and in serum $[12,13]$ from tobacco smokers.

Like CC16, SP-B is also a relatively small protein. In contrast, its circulating level primarily reflects the integrity of the alveolocapillary barrier, at least in patients with acute lung injury $[2,14]$. Serum SP-B levels have never been evaluated in tobacco smokers. In this study, the utility of serum CC16, SP-A and SP$\mathrm{B}$ as noninvasive markers of lung epithelial damage in tobacco smokers have been compared for the first time.

\section{Material and methods}

\section{Study population}

This study was approved by the Ethics Review Committee for Clinical Investigation of the Flinders Medical Centre (Adelaide, Australia) and by the local
Ethical Committee of the Faculty of Medicine of the Catholic University of Louvain (Brussels, Belgium).

Blood was sampled from the antecubital vein from nonsmokers: 55 males (52 yrs (20-60), median (range)) and 14 females (26 yrs (18-50)); and current smokers: 39 males (51 yrs (22-60)) and 15 females (32 yrs $(21-42)$ ) (table 1). Smokers had abstained from smoking for at least $2 \mathrm{~h}$ prior to sampling. All subjects completed a questionnaire concerning their occupational exposure, smoking habits and respiratory symptoms. Urine cotinine measurement was used to help validate smoking status. Although no subject had evidence or a history of cardiovascular or pulmonary disease, all of the older subjects (age $\geqslant 50$ yrs, 44 nonsmokers and 23 smokers) performed lung function tests. Samples were stored at $-80^{\circ} \mathrm{C}$ for batch analysis and were analysed in a blind randomised fashion.

\section{Analytical methods}

Clara cell secretory protein 16. CC16 was measured by latex immunoassay using rabbit anti-protein 1

Table 1. - Characteristics of the asymptomatic tobacco smokers and nonsmokers

\begin{tabular}{|c|c|c|c|}
\hline & Nonsmokers & Smokers & p-value \\
\hline Young population $\mathrm{n}$ & 25 & 31 & \\
\hline Age yrs & $29(18-50)$ & $34(21-50)$ & NS \\
\hline Serum creatinine $\mathrm{mg} \cdot \mathrm{dL}^{-1}$ & $1.34(0.99-1.76)$ & $1.36(0.95-1.76)$ & NS \\
\hline Cumulative smoking pack-yrs & & $14.9(2.5-54.0)$ & \\
\hline Current smoking cigarettes $\cdot$ day $^{-1}$ & & $19(3.5-70)$ & \\
\hline Old population $n$ & 44 & 23 & \\
\hline Age yrs & $54(50-60)$ & $54(53-60)$ & NS \\
\hline Serum creatinine $\mathrm{mg} \cdot \mathrm{dL}^{-1}$ & $1.05(0.78-1.52)$ & $1.06(0.79-1.37)$ & NS \\
\hline Cumulative smoking pack-yrs & & $30.8(0.8-78.0)$ & \\
\hline Current smoking cigarettes $\cdot$ day $^{-1}$ & & $17(1-40)$ & \\
\hline $\mathrm{FEV}_{1} / \mathrm{VC}$ & $0.85(0.70-0.99)$ & $0.85(0.70-0.92)$ & NS \\
\hline 95th percentile & $0.69(0.67-0.70)$ & $0.68(0.67-0.70)$ & NS \\
\hline VC & $4.40(3.29-6.68)$ & $4.27(2.91-5.42)$ & NS \\
\hline$\%$ pred & $94(73-132)$ & $89(51-110)$ & NS \\
\hline 95th percentile & $3.34(2.19-3.96)$ & $3.27(2.65-3.79)$ & NS \\
\hline FVC & $3.94(2.75-6.23)$ & $3.73(2.28-5.02)$ & NS \\
\hline$\%$ pred & $101(78-136)$ & $96(68-128)$ & NS \\
\hline 95th percentile & $3.43(2.19-4.09)$ & $3.36(2.69-3.93)$ & NS \\
\hline FEV1 & $3.32(2.43-4.68)$ & $3.05(1.87-3.99)$ & 0.04 \\
\hline$\%$ pred & $99(71-125)$ & $93(53-119)$ & NS \\
\hline 95th percentile & $2.56(1.7-3.02)$ & $2.53(2.02-2.93)$ & NS \\
\hline PEF & $462(239-614)$ & $445(263-577)$ & NS \\
\hline$\%$ pred & $92(47-126)$ & $96(50-111)$ & NS \\
\hline 95th percentile & $311(235-350)$ & $308(263-342)$ & NS \\
\hline FEF25 & $6.69(2.41-9.89)$ & $5.84(2.67-8.19)$ & NS \\
\hline$\%$ pred & $91(32-136)$ & $65(35-107)$ & NS \\
\hline FEF50 & $4.43(2.42-7.07)$ & $3.60(1.73-5.27)$ & 0.005 \\
\hline$\%$ pred & $93(55-166)$ & $84.5(37-112)$ & NS \\
\hline FEF75 & $1.66(0.76-3.19)$ & $1.41(0.53-2.95)$ & 0.03 \\
\hline$\%$ pred & $88(40-200)$ & $79(33-164)$ & NS \\
\hline FEF $25-75$ & $5.02(2.41-8.22)$ & $4.87(1.52-6.42)$ & NS \\
\hline$\%$ pred & $90(40-147)$ & $87(27-114)$ & NS \\
\hline 95th percentile & $3.92(3.37-4.32)$ & $3.93(3.61-4.12)$ & NS \\
\hline
\end{tabular}

Data are presented as median (range). The data have been stratified into those that underwent lung function testing (old population, age $\geqslant 50 \mathrm{yrs}$ ) and those that did not (young population, age $<50 \mathrm{yrs}$ ). FEV1: forced expiratory volume in one second; VC: vital capacity: FVC: forced VC; PEF: peak expiratory flow; FEF25, FEF50, FEF75: forced expired flow measured with a peak flow meter at $25 \%, 50 \%$ and $75 \%$ of expired volume respectively; FEF25-75: average forced expired flow between $25 \%$ and $75 \%$ of expired volume; $\%$ pred: percentage predicted. The associated 5 th percentiles (95th percentile) that define the lower limits of normal are shown for FEV1/VC, VC, FVC, PEF, and FEF25-75. Significant and nonsignificant (NS) differences between the nonsmokers and smokers are depicted. 
antibody (Dakopatts, Glostrup, Denmark) and CC16 purified in house [15]. The serum samples were heated at $56^{\circ} \mathrm{C}$ for $30 \mathrm{~min}$ and treated with polyethylene glycol $(16 \%, \mathrm{v} / \mathrm{v}, 1 / 1)$ and trichloroacetic acid $(10 \%, \mathrm{v} / \mathrm{v}, 1 / 40)$ to avoid possible interference by complement, rheumatoid factor or chylomicrons. All samples were analysed in duplicate at two different dilutions. The assay has a detection limit of $0.5 \mu \mathrm{g} \cdot \mathrm{L}^{-1}$ and an average analytical recovery of $95 \%$, with the intra- and interassay coefficients of variation ranging from 5 to $10 \%$.

Surfactant proteins- $A$ and -B. SP-A and -B were measured with enzyme-linked immunosorbent assay (ELISA) inhibition assays using polyclonal antibodies raised against alveolar proteinosis derived SP-A and mature SP-B, respectively [2]. Briefly, in order to free the SP-A and -B from any associated plasma or surfactant components, aliquots were first treated with ethylenediamine tetraacetic acid (EDTA), sodium dodecylsulphate (SDS), and Triton X-100. All samples were assayed in duplicate at four serial dilutions. Standards, assayed in quadruplicate, were included in each ELISA plate at eight serial dilutions (SP-A: 1.95-250 $\mu \mathrm{g} \cdot \mathrm{L}^{-1}$; SP-B: $\left.7.8-1000 \mu \mathrm{g} \cdot \mathrm{L}^{-1}\right)$. Absorbance was measured using a Dynatech MR5000 reader (Dynatech Laboratories, Chantilly, VA, USA). An AssayZap program (Biosoft, Ferguson, MO, USA) was used to generate a standard curve $(r>0.99)$ and to compute the concentration of SP-A and -B. The antibodies do not react with other plasma or alveolar epithelial lining fluid antigens and the assays have intra- and interassay coefficients of variation $<10 \%$ [2].

Other parameters. Serum creatinine was measured by Jaffe's method and used as an index of glomerular filtration rate. Cotinine was measured in urine by gas chromatography. Pulmonary function tests were evaluated (Vitalograph Compact II; Group Design and Manufacturing, Ennis, Co. Clare, Ireland) using the recommendations of the European Respiratory Society [16].

\section{Statistical analysis}

The Kolmogorov-Smirnov test with Lilliefors significance correction was used to test for normality. The distribution of CC16, SP-A, and SP-B in the smokers was clearly nonlinear $(\mathrm{p}=0.000, \mathrm{p}=0.000$ and $\mathrm{p}=0.008$, respectively). Therefore, nonparametric statistics were used. Unless otherwise stated, results are expressed as median (range). The Mann Whitney U-test or the Wilcoxon matched-pairs signed-ranks test was used for all comparisons. The association between measured variables was tested using the Spearman rank order correlation test. Statistical significance was assigned at $\mathrm{p}<0.05$.

Stepwise multiple linear regression analysis of the serum variables. The levels of plasma CC16, SP-A, and SP-B must be determined not just by their rate of entry into, but also their clearance from, the circulation. CC16 is freely eliminated by glomerular filtration, and the current authors have previously suggested that this may also be a major route of systemic SP-A and -B clearance [14]. Finally, there is an age and sex bias in the levels of many circulating antigens [17, 18]. Therefore, the present authors hypothesised that independent variables influencing serum CC16, SP-A, and SP-B were tobacco smoke exposure, serum creatinine, age and sex.

\section{Results}

\section{Smokers versus nonsmokers}

Whereas the concentration of serum SP-A was unchanged in the smokers, SP-B was increased $(p=0.0001)$ and CC16 decreased $(p=0.0014)$ (fig. 1). These differences were accentuated by expressing the data as the SP-A/CC16 $(\mathrm{p}=0.0019)$ and SP-B/CC16 $(\mathrm{p}=0.0000)$.

\section{Determinants}

Nonsmokers. CC16 was positively influenced by age, whereas SP-A and -B were negatively influenced by creatinine (table 2 ).

Smokers. When cumulative smoking (pack-yrs) and current smoking (cigarettes per day) status was included in the analyses of the levels of the pneumoproteins in the smokers, none of the variables emerged as significant determinants for serum $\mathrm{CC} 16$ or SP-A. In contrast, serum SP-B was positively influenced by cumulative smoking (fig. 2a) and current smoking (fig. 2b). Cumulative smoking and current smoking were analysed as separate independent variables in the stepwise multiple linear regression analysis since they were strongly cross-correlated $(\mathrm{r}=0.39, \mathrm{p}=0.006)$ (table 2).

Combined. When the data from the smokers and nonsmokers was combined, CC16 was negatively influenced by cumulative smoking and continued to be positively influenced by age. SP-A and -B were negatively influenced by creatinine and positively influenced by cumulative smoking (table 2). When the analyses were repeated using current smoking as an independent variable instead of cumulative smoking, similar influences immerged (CC16: $\mathrm{r}^{2}=0.35$, SP-A: $\mathrm{r}^{2}=0.07$, SP-B: $\mathrm{r}^{2}=0.48$ ).

\section{Proteinaemia co-relationships}

Serum SP-B was related to SP-A in both the smokers $\left(\mathrm{r}_{\mathrm{s}}=0.44, \mathrm{p}=0.014\right)$ and nonsmokers $\left(\mathrm{r}_{\mathrm{s}}=0.29\right.$, $\mathrm{p}=0.017$ ). Serum CC16 was only related to SP-A in the smokers $\left(r_{s}=0.43, p=0.003\right)$ and not related to SP-B.

Age. Serum CC16, SP-A and SP-B were related to age in the smokers $\left(C C 16: r_{s}=0.44, p=0.003 ; S P-A: r_{s}=0.41\right.$, $\mathrm{p}=0.002 ;$ SP-B: $\left.\mathrm{r}_{\mathrm{s}}=0.37, \mathrm{p}=0.006\right)$ and nonsmokers 

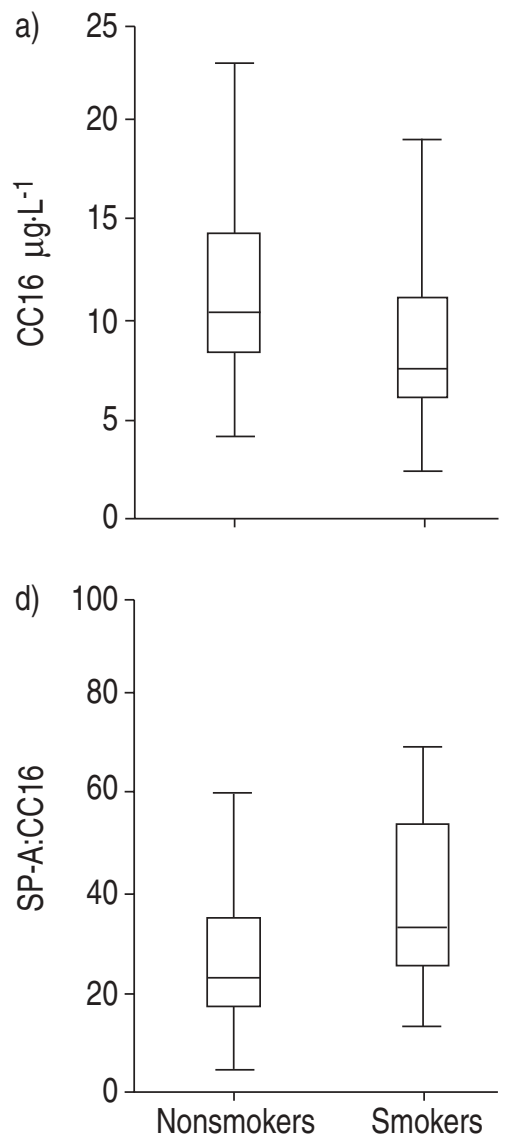
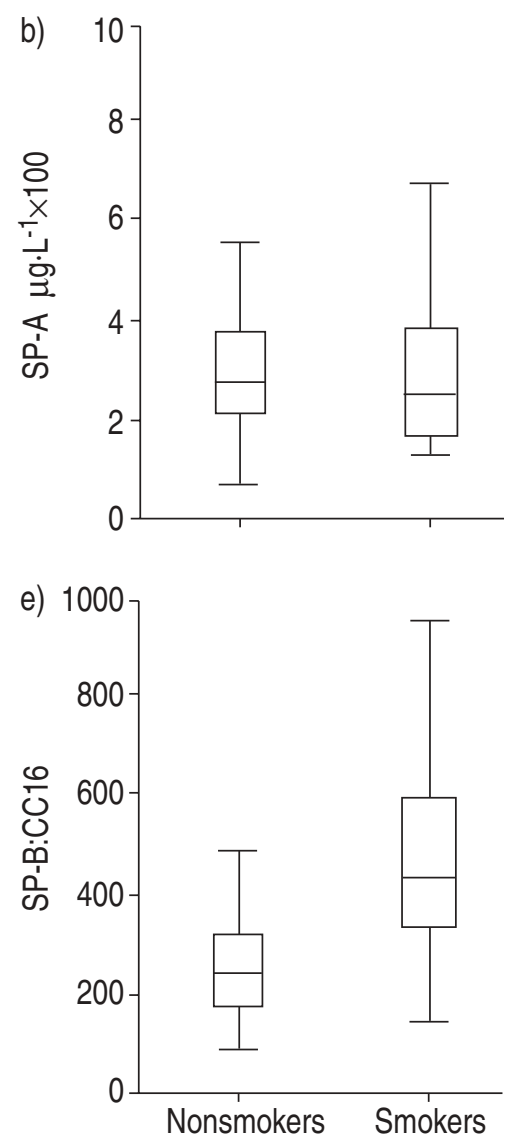

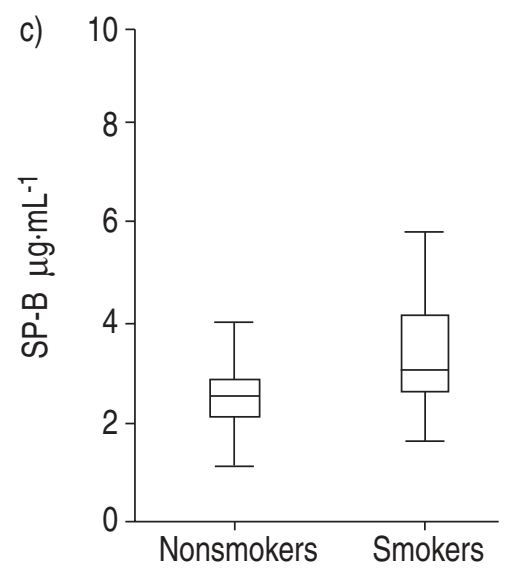

Fig. 1. - The quartiles of Clara cell secretory protein 16 (CC16), surfactantassociated protein (SP)-A and SP-B, and the ratio of SP-A and SP-B relative to CC16 (SP-A:CC16 and SP-B:CC16) in serum from asymptomatic tobacco smokers and nonsmokers.
(CC16: $\mathrm{r}_{\mathrm{s}}=0.57, \mathrm{p}=0.000 ; \quad \mathrm{SP}-\mathrm{A}: \mathrm{r}_{\mathrm{s}}=0.27, \mathrm{p}=0.025$; SP-B: $r_{s}=0.38, p=0.001$ ) (fig. 3).

Renal function. Both serum SP-A and SP-B were inversely related to creatinine in the smokers (SP-A: $r_{s}=-0.39, \quad p=0.012 ; \quad$ SP-B: $\left.\quad r_{s}=-0.54, \quad p=0.000\right)$ and nonsmokers (SP-A: $r_{s}=-0.38, p=0.002$; SP-B: $r_{s}=-0.41$, $\mathrm{p}=0.001)$. Conversely, serum CC16 was inversely related to creatinine only in the nonsmokers $\left(\mathrm{r}_{\mathrm{s}}=-0.27, \mathrm{p}=0.036\right)$.

When the females were age matched with a subgroup of males, serum creatinine was greater in the latter in both smokers $(1.48(1.28-1.76)$ versus 1.24 $\left.(0.95-1.50) \mathrm{mg} \cdot \mathrm{dL}^{-1}, \mathrm{p}=0.002\right)$ and nonsmokers $(1.48$ (1.32-1.76) versus $\left.1.25(0.99-1.61) \mathrm{mg} \cdot \mathrm{dL}^{-1}, \mathrm{p}=0.02\right)$. Creatinine inversely reflected age in both the smokers $\left(\mathrm{r}_{\mathrm{s}}=-0.59, \mathrm{p}=0.002\right)$ and nonsmokers $\left(\mathrm{r}_{\mathrm{s}}=-0.54\right.$, $\mathrm{p}=0.000)$.

Sex

When the females were age matched with a subgroup of males, serum CC16, SP-A and SP-B were similar in male and female nonsmokers. SP-A was also similar in male and female smokers, although serum SP-B was higher in female smokers $(3,344$ $(2,409-6,306)$ versus $2,446 \quad(1,589-4,101) \mu \mathrm{g} \cdot \mathrm{L}^{-1}$, $\mathrm{p}=0.013)$ and $\mathrm{CC} 16$ was lower (5.4 (2.4-7.6) versus $\left.7.5(4.4-11.9) \mu \mathrm{g} \cdot \mathrm{L}^{-1}, \mathrm{p}=0.027\right)$ even though cumulative smoking exposure was similar (male: 14.1 (2.5-47.5); female: 14.7 (4.0-54) pack-yrs).

\section{Lung function}

Although the lung function of the smokers was less than that in the nonsmokers, with a slight decrement in the forced expired volume after one second (FEV1) and the forced expired flow measured with a peak flow meter at 50 and $75 \%$ of expired volume (table 1), none of the smokers had obstructive disease as defined by the European Respiratory Society [16] and the American Thoracic Societies [19]. All subjects had a FEV1/vital capacity (VC) ratio $>95$ th percentile, defined as the lower limit of normal. Nevertheless, $\mathrm{FEV} 1 / \mathrm{VC}$ was inversely related to cumulative smoking $\left(r_{s}=-0.39, p=0.002\right)$ (fig. 4a). Serum SP-B was inversely correlated with various respiratory parameters in both the smokers and nonsmokers (table 2). In particular, SP-B was inversely related to $\mathrm{FEV} 1 / \mathrm{VC}$ (fig. 4b, table 3). Weaker relationships were observed with SP-A (not shown). CC16 did not relate to any respiratory parameter.

\section{Discussion}

It was found that whereas serum SP-B was strongly correlated with tobacco smoke exposure, CC16 was decreased in smokers. The authors suggest that the 
Table 2. - Stepwise multiple linear regression analysis of serum Clara cell secretory protein 16 (CC16), surfactantassociated protein (SP)-A and -B

\begin{tabular}{lcccc}
\hline & $\mathrm{r}^{2}$ & $\mathrm{~F}$ & $\mathrm{p}$-value & $\beta$ \\
\hline $\begin{array}{l}\text { Nonsmokers } \\
\text { CC16 }\end{array}$ & & & & \\
$\quad$ Age & 0.29 & 25.1 & 0.0000 & 0.54 \\
SP-A & & & & \\
$\quad$ Creatinine & 0.08 & 5.1 & 0.027 & -0.28 \\
SP-B & & & & \\
$\quad$ Creatinine & 0.25 & 20.3 & 0.0000 & -0.50 \\
Smokers & & & & \\
$\quad$ SP-B & & & & \\
$\quad$ Pack-yrs & 0.52 & 48.3 & 0.0000 & 0.72 \\
$\quad$ Cigarette-day ${ }^{-1}$ & 0.15 & 8.3 & 0.0059 & 0.39 \\
Combined & & & & \\
CC16 & 0.35 & 24.4 & 0.0000 & \\
$\quad$ Age & & & 0.0000 & 0.56 \\
$\quad$ Pack-yrs & 0.14 & 7.4 & 0.0062 & -0.23 \\
SPA & & & 0.001 & \\
$\quad$ Creatinine & & & 0.0121 & -0.28 \\
$\quad$ Pack-yrs & & & 0.24 \\
SP-B & 0.62 & 76.2 & 0.0000 & \\
$\quad$ Creatinine & & & 0.0000 & -0.33 \\
$\quad$ Pack-yrs & & & 0.0000 & 0.72 \\
\hline
\end{tabular}

Determinants of CC16, SP-A and SP-B identified using stepwise multiple linear regression analysis where independent variables with the least significance $(p>0.05)$ were sequentially omitted. The authors hypothesised that the independent variables influencing serum CC16, SP-A, and SP-B were tobacco smoke exposure, serum creatinine, age and sex. Tobacco smoking was expressed as cumulative smoking (pack-yrs) and current smoking (cigarettes $\cdot$ day $^{-1}$ ).

increased SP-B reflects increased alveolocapillary leakage, whereas the decreased $\mathrm{CC} 16$ reflects the toxic effects of tobacco smoke on Clara cells.

Pulmonary function in smokers: airway and parenchymal disease

Tobacco smoke contains 2,000-4,000 agents including carbon monoxide, nicotine, carcinogens (aromatics hydrocarbons), oxidants and irritants (acrolene, aldehydes), which can exert toxic effects at different levels of the respiratory tract (bronchial and alveolar). In addition, tobacco smoke contains microparticles that can deposit within bronchioles and alveoli. Active smoking, and probably also passive smoking, provokes physiological and pathological changes that alter lung integrity and function. Indeed, it was found that FEV1 was reduced in the older smokers compared to the age matched nonsmokers, possibly reflecting early obstructive disease.

Whilst tobacco smoking is recognised to contribute to COPD, tobacco smoking also increases lung epithelial permeability. Acute, reversible changes in permeability probably arise through smoke-mediated release of vasoactive neuropeptides (tachykinins) [9] from sensory nerves in the airways whereas chronic increases may reflect early destruction of connective tissue in the alveoli [20-22]. Tars and other noxious substances in cigarette smoke increase the numbers of lung neutrophils in both symptomatic and asymptomatic smokers [23]. The term "frustrated phagocyte" has been coined to refer to the inability of phagocytic cells to either ingest or inactivate foreign material, e.g. cigarette smoke tars. In such cases this leads to a worsening cycle of neutrophil recruitment and activation, as the foreign material continues to accumulate, and may ultimately result in chronic tissue damage.

\section{Study design and validation of methods}

The assays in this study have been validated using independently sourced monoclonal and polyclonal antibodies $[2,15,24]$. The levels of circulating CC16, SP-A and SP-B in the normal subjects in this study were similar to those previously reported by the current authors [2, 3, 24]. Although no one else has studied the leakage of SP-B, the serum levels of CC16 and SP-A in this study are higher than those described by NOMORI and colleagues $[7,11]$. However, it is likely that serum lipids interfere with their CC16 determinations $[25,26]$. Moreover, native SP-A resides as an
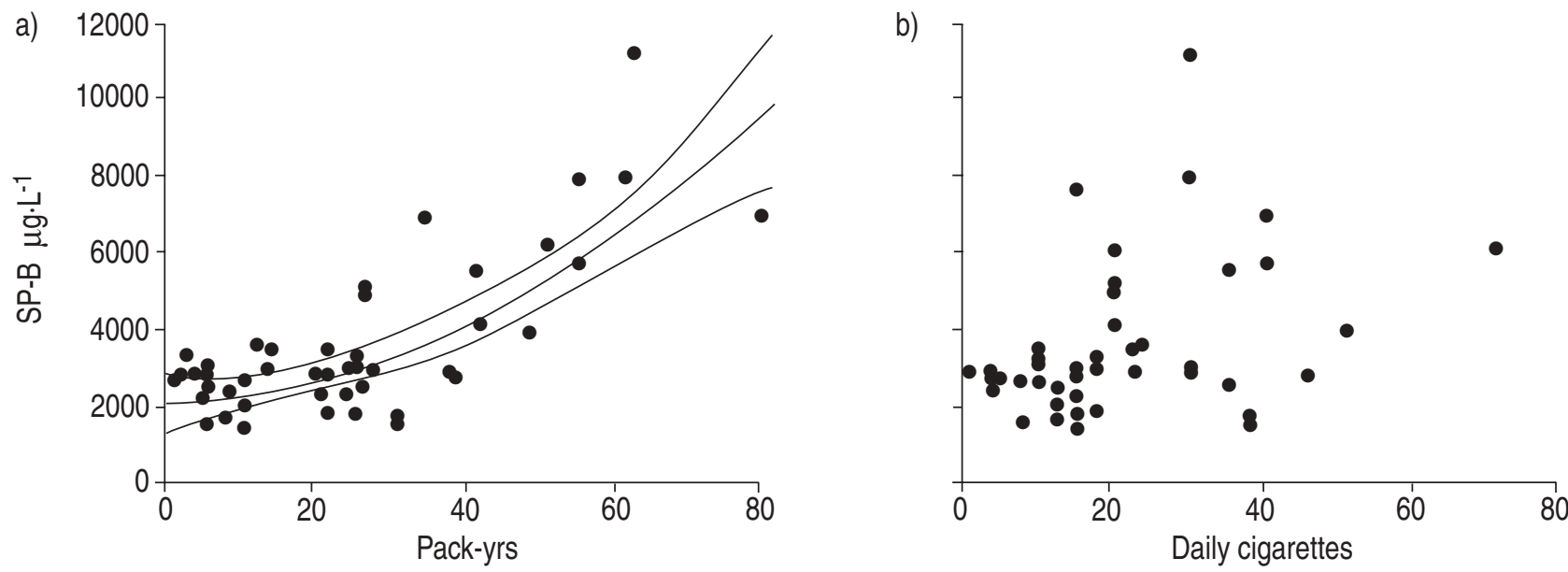

Fig. 2. - The relationship between serum surfactant-associated protein-B (SP-B) and tobacco smoking expressed as a) cumulative smoking and b) current smoking in smokers. A second-order polynomial curve is fitted and $95 \%$ confidence intervals displayed in a). 

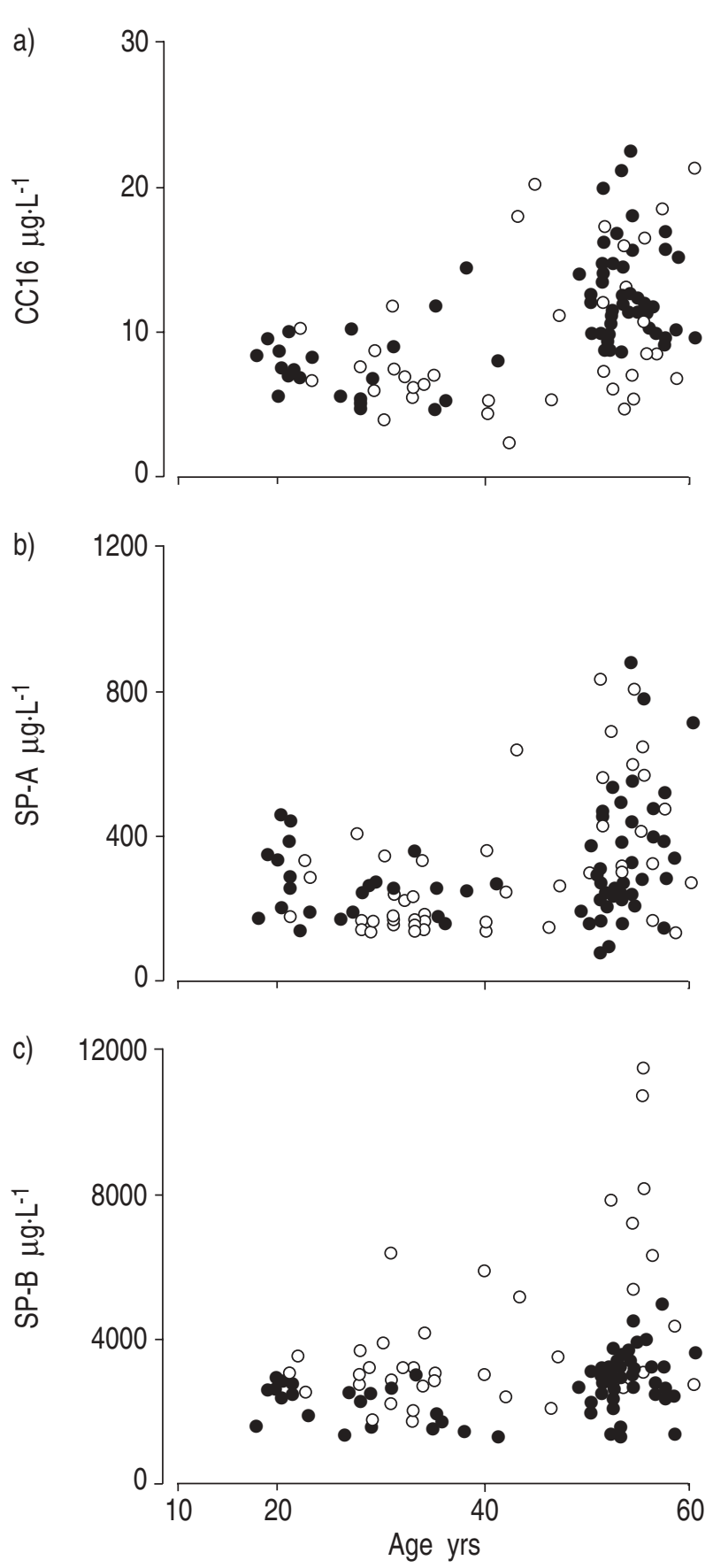

Fig. 3.-The relationship between serum a) Clara cell secretory protein $16(\mathrm{CC} 16)$, b) surfactant-associated protein (SP)-A and c) SP-B and age in nonsmokers $(\bullet)$ and smokers $(\bigcirc)$.

oligomer with a highly organised quaternary structure usually comprising 18 monomers $\left(\mathrm{M}_{\mathrm{r}} \sim 650 \mathrm{kDa}\right)$ and distinct binding domains for phospholipids, calcium, carbohydrates, glycolipids and lipopolysaccharides. Native SP-B also strongly associates with lipids. The assay procedure in this study incorporates EDTA to disrupt the $\mathrm{Ca}^{2+}$-lipid bridges, and SDS and Triton-X 100 to dissociate the proteins and to free them from any associated components. Clearly, only with such pretreatment can antigenic sites be exposed and a true estimation of concentration be achieved. Indeed, when the analyses were repeated without the use of these reagents, the serum SP-A and -B determinations were greatly reduced, and the SP-A levels were similar to those described by NomORI and colleagues [7, 11].

Finally, SP-B undergoes extensive post-translational modification. Although the exact nature of the SP-B antigens in blood remains to be clarified [2], the current authors have recently analysed plasma from an infant, independently confirmed by two laboratories to have an autosomal recessive frame shift mutation at 121 base pairs in the SP-B gene, which resulted in a premature stop codon such that no SP-B messenger ribonucleic acid or protein was produced. Analysis of this definitive negative control has confirmed that the assay used in this study does indeed measure immunoreactive SP-B (unpublished data). Therefore, the present authors do not believe that their serum determinations were influenced by nonspecific reactivities. It is difficult to conceive that the strong correlation observed with the serum determinations here was fortuitous, given that the proteins share few structural similarities.

In smokers that have abstained for $12 \mathrm{~h}$, MORRISON et al. [23] have shown that the 50\% lung clearance of technetium-99m labelled diethylenetriamine pentaacetate $\left({ }^{99 \mathrm{~m}}\right.$ Tc-DTPA) is $\sim 17 \mathrm{~min}$, whereas it is $\sim 15 \mathrm{~min}$ in smokers that have abstained for only $1 \mathrm{~h}$. In order to minimise the small acute effect of smoking on alveolocapillary leakage, the smokers in this study abstained for at least $2 \mathrm{~h}$ prior to blood sampling.

In this study, serum creatinine was used as an index of renal function, although it is appreciated that serum creatinine is influenced by other factors. Indeed, serum creatinine was slightly lower in the females than males and inversely related to age. The current authors believe that these small differences most likely reflect variations in muscle mass rather than renal function. Finally, although nonparametric analysis was used, the findings remain robust when analysed using parametric statistics.

\section{Determinants of circulating levels of lung proteins in} smokers

It was found that serum SP-B was increased in the smokers in a manner influenced by both pack-yrs and the number of cigarettes per day, whereas serum CC16 was decreased in smokers (consistent with previous findings) $[12,13]$. Although SP-A was not increased, its levels were influenced by tobacco exposure. These findings are in contrast to those of Nomori and colleagues $[7,11]$ who found that serum CC16 was not significantly different in smokers and that serum SP-A did not correlate with the amount of cigarette smoking. It is likely that the discrepancies reflect differences in assay specificity $[25,26]$ and sensitivity.

Intuitively, circulating levels of the lung proteins will be influenced by their rates of entry into the circulation and by their rates of plasma clearance.

Systemic clearance. In the circulation, $30-80 \%$ of low molecular weight plasma proteins are cleared by glomerular filtration [27], while the remainder leak 

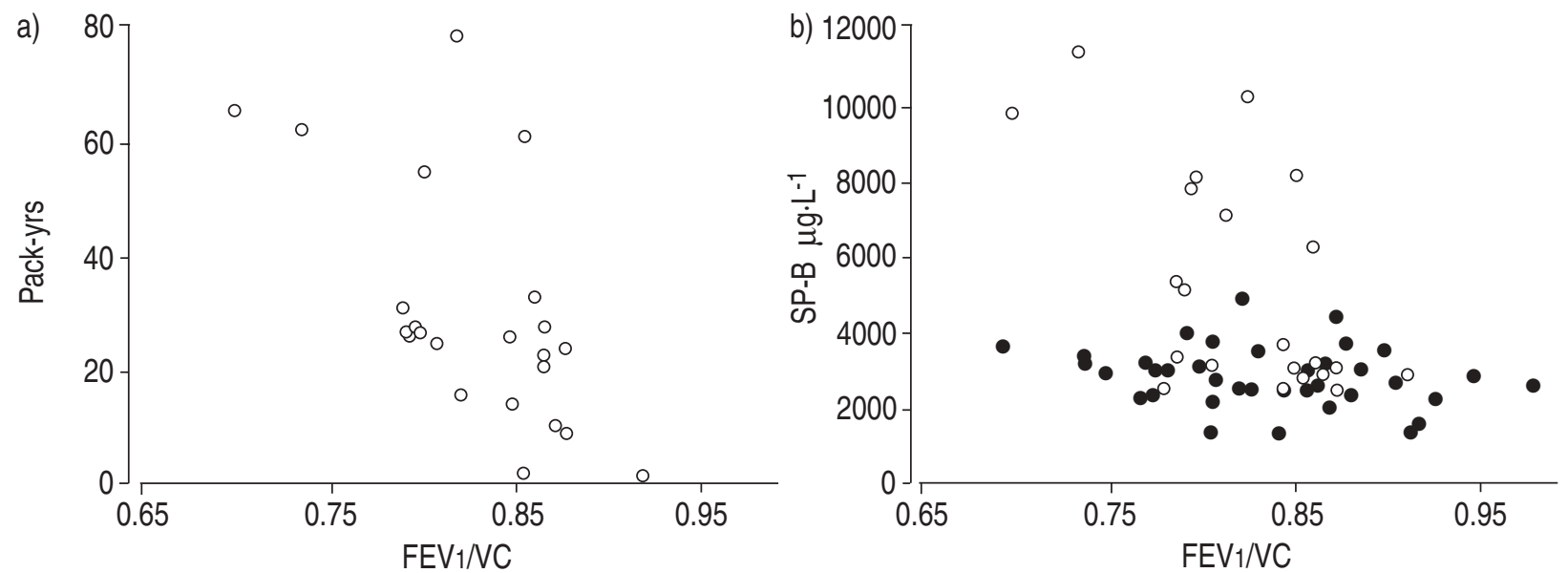

Fig. 4. - The relationship between a) cumulative smoking (pack-yrs), b) serum surfactant protein-B (SP-B) and the ratio of forced expired volume after one second $\left(\mathrm{FEV}_{1}\right)$ to vital capacity $(\mathrm{VC})$ in nonsmokers $(\mathbf{O})$ and smokers $(\bigcirc)$.

Table 3.-Relationship between serum surfactantassociated protein (SP)-B and respiratory parameters in older asymptomatic tobacco smokers and nonsmokers

\begin{tabular}{|c|c|c|c|c|c|c|}
\hline \multirow[t]{2}{*}{ Parameter } & \multicolumn{2}{|c|}{ Nonsmokers } & \multicolumn{2}{|c|}{ Smokers } & \multicolumn{2}{|c|}{ Combined } \\
\hline & $\mathrm{r}_{\mathrm{s}}$ & p-value & $r_{s}$ & $\mathrm{p}$-value & $r_{s}$ & p-value \\
\hline $\mathrm{VC}$ & -0.06 & 0.38 & -0.06 & 0.350 & -0.11 & 0.192 \\
\hline FEV1 & -0.22 & 0.164 & -0.19 & 0.115 & -0.23 & 0.031 \\
\hline PEF & -0.02 & 0.470 & -0.46 & 0.001 & -0.24 & 0.029 \\
\hline FEF25 & -0.01 & 0.48 & -0.50 & 0.000 & -0.41 & 0.000 \\
\hline FEF50 & -0.21 & 0.180 & -0.25 & 0.054 & -0.31 & 0.007 \\
\hline FEF75 & -0.48 & 0.012 & -0.32 & 0.018 & -0.42 & 0.000 \\
\hline FEV1/VC & -0.35 & 0.113 & -0.26 & 0.096 & -0.51 & 0.000 \\
\hline
\end{tabular}

VC: vital capacity; FEV1: forced expiratory volume in one second; PEF: peak expiratory flow; FEF25, FEF50, FEF75: forced expired flow measured with a peak flow meter at $25 \%$, $50 \%$ and $75 \%$ of expired volume respectively.

into other tissue pools, ultimately to be metabolised or catabolised to amino acids and recycled. However, systemic clearance is not a major determinant of circulating levels of lung proteins in patients with acute lung injury [14] and is unlikely to be altered in the smokers in this study. Indeed, if the kidney were a major determinant of circulating levels of the lung proteins, an inverse association would be expected with renal function. Here, the opposite was found; high levels of serum creatinine were associated with low levels of serum CC16, SP-A and SP-B, a finding that most likely reflects the secondary effect of age on muscle mass and lung structure.

Therefore, the circulating levels of CC16, SP-A and SP-B must reflect "leakage" into the circulation. This, in turn, could reflect the extent of transcytosis, basal secretion, the concentration gradient or the permeability of the alveolocapillary membrane.

Lung leakage. The route by which the lung proteins enter the circulation is polemic. Indeed, there is no agreement about either the "normal" permeability of the alveolocapillary barrier or the location and nature of the "leakage" sites. However, it is generally accepted that the epithelium, rather than the endothelium, provides the major barrier to the movement of water and solutes. With the possible exception of albumin and a few other proteins, there is no evidence of receptor-mediated active transcytosis across alveolar type I and type II cells [28]. Restricted diffusion of intact protein across the alveolar epithelium accounts for $>90 \%$ of alveolar protein clearance [28]. Basolateral secretion of CC16, SP-A or SP-B has never been described and nonetheless, lung lymph accounts for only $\sim 25 \%$ of total lung protein clearance from the interstitium [29]. Consistent with this, the current authors have previously estimated that, at least in respect to SP-A and -B, pleural concentrations and rates of lymph flow are insufficient to account for the relative concentration changes that occur in these proteins in the circulation [30]. Tobacco smoking decreases lung levels of CC16 [3, 31, 32] and may explain, at least in part, the reduced levels of this protein in the circulation of the smokers in this study. However, tobacco smoking either has no effect, or reduces, the lung levels of SP-A and -B [8, 32-36]. Consequently, the current authors believe that increased alveolocapillary permeability, and not increased transcytosis, basolateral secretion or alveolar pool size, is the major determinant of the increased circulating levels of SP-B in smokers.

\section{Pneumoproteinaemia in smokers}

Serum SP-B, and to a lesser extent SP-A, was inversely correlated with $\mathrm{FEV} 1 / \mathrm{VC}$ and other parameters of airflow, suggestive of an association between obstructive disease and parenchymal lung health. Although it could be argued that these relationships are secondary to their association with age, this is unlikely given the narrow range of different ages in the subjects that underwent lung function tests ( $\leqslant 10 \mathrm{yrs}$ ) and the fact that lung function was not related to serum SP-B in the nonsmokers.

Since serum SP-A and -B were correlated, it is 
presumed that both proteins enter the circulation via the same route and that SP-B is a more sensitive indicator of alveolocapillary leakage by virtue of its smaller size; native $\mathrm{M}_{\mathrm{r}} \sim 18$ compared with $\sim 650 \mathrm{kDa}$ [2]. Since Clara cells have a high content of xenobiotic metabolising enzymes, they are probably progressively destroyed by toxic metabolites of tobacco smoke generated via the cytochrome P450 system and might be involved in the progressive destruction of lung parenchyma in smokers. Although the bronchoalveolar lavage fluid (BALF) level of $\mathrm{CC} 16$ from tobacco smokers is typically reduced by half $[3,31,32]$, serum CC16 in the patients here was only reduced by $<20 \%$. This differential presumably reflects the increased alveolocapillary leakage responsible for the elevated circulating surfactant proteins.

Consistent with the findings in this study, tobacco smokers not only have increased pulmonary clearance of ${ }^{99 \mathrm{~m}}$ Tc-DTPA [23, 37], but also increased albumin leakage [36, 38]. Although the mechanism for the chronic increase in leakage is unknown, recent findings suggest that the changes are associated with repeated inflammatory-mediated acute lung injury, increased oxidant load [23] and depletion of antioxidants including glutathione [37]. Cytochrome P450 may also biotransform the tobacco specific carcinogens to 4-(methylnitrosamine)-1-(-3-pyridine)1-butadone (NNK). If so, both alveolar type II cells and macrophages may be target cells for NNK toxicity [39].

The effect of age. The current authors have previously reported that $\mathrm{CC} 16$ increases with age in nonsmokers [13] and they now report that the same is also true of SP-A and -B. Indeed, the levels of SP-A and -B in the nonsmokers in this study were $~ 50 \%$ higher than previously reported in subjects $\sim 25$ yrs younger [2]. Again in this study, the findings with regards to SP-A are contrary to those of NOMORI et al. [11] and as discussed above the differences are probably due to assay sensitivity.

Age-related structural and functional changes in the lung have been previously described. Gas trapping increases with age [40], as do airspace abnormalities [41] and diameter [42], whereas lung compliance and shear modulus decrease [43] in association with increased lung elastin content [44]. Moreover, whereas the internal surface area of the lung increases to a maximum of $\sim 80 \mathrm{~m}^{2}$ at the age of $\sim 20 \mathrm{yrs}$, it decreases $\sim 2.7 \mathrm{~m}^{2}$ per decade thereafter [45]. Finally, increased albumin levels have been reported in BALF from old subjects [46]. No information is available on the effect of age on the alveolar levels of SP-A or SP-B. However, since $\mathrm{CC} 16$ expression is not related to age [47], the present authors suggest that the agerelated pneumoproteinaemia in nonsmokers reflects increased alveolocapillary leakage and the effects of nonspecific deterioration of the lung.

Sex. Although Hanley et al. [48] have reported that oestrogen accelerates and testosterone delays cutaneous barrier formation, the female smokers in this study had higher levels of serum SP-B and lower levels of $\mathrm{CC} 16$ than the males, suggesting worse injury despite similar cumulative smoking exposure. LANGHAMMER et al. [49] have recently reported that female smokers are $50 \%$ more likely to sustain respiratory problems such as wheezing, breathlessness and asthma than male smokers. Since the volume and surface area of a female's lung are generally $\sim 25-30 \%$ smaller than a male's [50, 51], even when matched for body size and height, the smoke burden is proportionally greater for a given smoking habit. Therefore, this could explain the greater injury apparent in the female cohort.

The utility of serum Clara cell secretory protein 16, surfactant-associated protein- $A$ and $-B$

If one assumes that serum SP-B, and to a lesser extent SP-A, reliably reflects the leakage of the lung epithelial barrier to proteins, then SP-A/CC16 and SP$\mathrm{B} / \mathrm{CC} 16$ should allow the extent of Clara cell damage to be better evaluated, by normalising for changes in CC16 leakage. Even without this assumption, the ratios appear to be useful indices, integrating components of both cellular toxicity and epithelial barrier function. Potentially, the concept of pneumoproteinaemia has the equivalent utility to that of monitoring proteinuria in kidney diseases, since the passage of proteins across the lung barrier is governed by similar structural and functional features as that of glomerular filtration. Consequently, the use of different biomarkers, produced by distinct regions of the respiratory tract, may allow evaluation of present and past exposures to toxins, detection of early defects, identification of susceptible individuals, derivation of acceptable exposure levels and help establish causal associations between effects and putative toxic agents.

\section{Study limitations}

The levels of the pneumoproteins varied appreciable in the nonsmokers. At least some of this diversity is due to the influence of age. Larger studies are needed to determine normal variance before the utility of pneumoproteinaemia can be fully exploited. Finally, although urine cotinine correlated with the selfreported smoking status of the subjects (not shown), better controlled studies are required to standardise the various variables associated with the smokers' brand habits. However, the strength of the data despite these limitations further underpins the potential utility of pneumoproteins as markers of parenchymal lung health.

In conclusion, although the alveolocapillary barrier is normally extraordinarily effective at partitioning the plasma from the alveolar epithelial lining fluid, the present study provides strong evidence that tobacco smoking causes a chronic increase in the permeability of the lung parenchyma. In serum, the simultaneous determination of various lung-specific secretory proteins represents a new and original approach for the noninvasive assessment of the integrity of the lung epithelium. As expected, Clara cell secretory protein 16 , surfactant-associated protein-A and $-\mathrm{B}$, which are 
all highly specific to the lung, are good candidate markers. Of the markers studied so far, surfactantassociated protein-B appears the most promising. Potentially, their determination allows cellular toxicity (Clara cell secretory protein 16) to be distinguished from increased epithelial leakage (surfactantassociated protein-B $>$ surfactant-associated protein-A) in tobacco smokers.

\section{References}

1. Hermans C, Bernard A. Lung epithelium specific proteins: characteristics and potential applications as markers. Am J Respir Crit Care Med 1999; 159: 646678.

2. Doyle IR, Nicholas TE, Bersten AD. Surfactant proteins $\mathrm{A}$ and $\mathrm{B}$ are elevated in plasma of patients with acute respiratory failure. Am J Respir Crit Care Med 1997; 156: 1217-1229.

3. Bernard A, Marchandise FX, Depelchin S, Lauwerys $\mathrm{R}$, Sibille Y. Clara cell protein in serum and bronchoalveolar lavage. Eur Respir J 1992; 5: 12311238.

4. Abe S, Honda Y, Ando M, et al. Clinical significance of levels of lung surfactant protein A in serum, in various lung diseases. Nippon Kyobu Shikkan Gakkai Zasshi 1995; 33: 1219-1225.

5. Kuroki Y, Tsutahara S, Shijubo N, et al. Elevated levels of lung surfactant protein $\mathrm{A}$ in sera from patients with idiopathic pulmonary fibrosis and pulmonary alveolar proteinosis. Am Rev Respir Dis 1993; 147: 723-729.

6. Okamoto Y, Yoneda T, Tokuyama T, et al. Serum pulmonary surfactant protein A in asbestosis and asbestos-exposed workers. Am J Respir Crit Care Med 1997; 155: A808.

7. Nomori H, Horio H, Fuyuno G, Kobayashi R, Morinaga S, Hirabayashi Y. Protein 1 (Clara cell protein) serum levels in healthy subjects and patients with bacterial pneumonia. Am J Respir Crit Care Med 1995; 152: 746-750.

8. Lesur O, Bernard A, Begin RO. Clara cell protein (CC16) and surfactant associated protein A (SP-A) in asbestos-exposed workers. Chest 1996; 109: 467-474.

9. Wu ZX, Lee LY. Airway responsiveness induced by chronic exposure to cigarette smoke in guinea pigs: role of tachykinins. J Appl Physiol 1999; 87: 16211628.

10. Kida K, Oda H, Yamano Y, Kagawa J. Effects of cigarette smoking on the serum concentration of lung surfactant protein A (SP-A). Eur Respir J 1997; 10: 2124-2126.

11. Nomori H, Horio H, Fuyuno G, Kobayashi R, Morinaga S, Suemasu K. Serum surfactant protein A levels in healthy individuals are increased in smokers. Lung 1998; 176: 355-361.

12. Bernard A, Roels H, Buchet JP, Lauwerys R. Decrease of serum Clara cell protein in smokers. Lancet 1992; 339: 1620.

13. Bernard AM, Roels HA, Buchet JP, Lauwerys RR. Serum Clara cell protein: an indicator of bronchial cell dysfunction caused by tobacco smoking. Environ Res 1994; 66: 96-104.

14. Doyle IR, Hermans C, Bernard A, Nicholas TE, Bersten AD. Clearance of Clara cell secretory protein
16 (CC16) and surfactant proteins A and B from blood in acute respiratory failure. Am $J$ Respir Crit Care Med 1998; 158: 1528-1535.

15. Bernard A, Lauwerys R, Noël A, Vandeleene B, Lambert A. Determination by latex immunoassay of protein 1 in normal and pathological urine. Clin Chim Acta 1991; 201: 213-216.

16. Quanjer PH, Tammeling GJ, Cotes JE, Pedersen OF, Peslin R, Yernault JC. Lung volumes and forced ventilatory flows. Report Working Party Standardization of Lung Function Tests, European Community for Steel and Coal. Official Statement of the European Respiratory Society. Eur Respir J 1993; Suppl. 16, 540.

17. Kabanda K, Jadoul M, Pochet JM, et al. Determinants of the serum concentrations of low molecular weight proteins in patients on maintenance hemodialysis. Kidney Int 1994; 45: 1689-1696.

18. Kabanda K, Goffin E, Bernard A, Lauwerys R, van Ypersele de Strihou C. Factors influencing serum levels and peritoneal clearances of low molecular weight proteins in continuous ambulatory peritoneal dialysis. Kidney Int 1995; 48: 1946-1952.

19. Official Statement of the American Thoracic Society. Lung function testing: Selection of reference values and interpretative strategies. Am Rev Respir Dis 1991; 144: 1202-1218.

20. Nadel JA, Borson DB. Modulation of neurogenic inflammation by neutral endopeptidase. $\mathrm{Am}$ Rev Respir Dis 1991; 43: S33-S36.

21. Jones JG, Minty BD, Lawler P, Hulands G, Crawley $\mathrm{JC}$, Veall N. Increased alveolar epithelial permeability in cigarette smokers. Lancet 1980; 1: 66-68.

22. Nery LE, Florencio RT, Sandoval PR, Rodrigues RT, Alonso G, Mason GR. Additive effects of exposure to silica dust and smoking on pulmonary epithelial permeability: a radioaerosol study with technetium99m labelled DTPA. Thorax 1993; 48: 264-268.

23. Morrison D, Rahman I, Lannan S, MacNee W. Epithelial permeability, inflammation, and oxidant stress in the air spaces of smokers. Am J Respir Crit Care Med 1999; 159: 473-479.

24. Doyle IR, Nicholas TE, Bersten AD. Serum surfactant protein A levels in patients with acute cardiogenic pulmonary edema and adult respiratory distress syndrome. Am J Respir Crit Care Med 1995; 152: 307-317.

25. Hermans C, Aly O, Nyberg BI, Peterson C, Bernard A. Determinants of Clara cell protein (CC16) concentration in serum: a reassessment with two different immunoassays. Clin Chim Acta 1998; 272: 101-110.

26. Nomori H, Horio H, Takagi M, Kobayashi R, Hirabayashi Y. Clara cell protein correlation with hyperlipidemia. Chest 1996; 110: 583-584.

27. Guder WG. Proteinuria: causes, forms and methods of determination. Clin Diag Lab Med 1998; 1: 49-55.

28. Folkesson HG, Matthay MA, Weström BR, Kim KJ, Karlsson BW, Hastings RH. Alveolar epithelial clearance of protein. J Appl Physiol 1996; 80: 1431-1445.

29. Berthiaume Y, Albertine KH, Grady M, Fick G, Matthay MA. Protein clearance from the air spaces and lungs of unanesthetized sheep over $144 \mathrm{~h} . J \mathrm{Appl}$ Physiol 1989; 67: 1887-1897.

30. Doyle IR, Nicholas TE, Bersten AD. Partitioning lung and plasma proteins: circulating surfactant proteins as biomarkers of alveolocapillary permeability. Clin Exp Pharmacol Physiol 1999; 26: 185-197. 
31. Shijubo N, Itoh Y, Yamaguchi T, et al. Serum and BAL Clara cell $10 \mathrm{kDa}$ protein (CC10) levels and CC10-positive bronchiolar cells are decreased in smokers. Eur Respir J 1997; 10: 1108-1114.

32. Shijubo N, Honda Y, Itoh Y, et al. BAL surfactant protein $\mathrm{A}$ and Clara cell $10-\mathrm{kDa}$ protein levels in healthy subjects. Lung 1998; 176: 257-265.

33. Honda Y, Takahashi H, Kurori Y, Akino T, Abe S. Decreased contents of surfactant proteins A and D in BAL fluids of healthy smokers. Chest 1996; 109: 10061009.

34. Baughman RP, Whitsett JA. The effect of cigarette smoking on surfactant apoprotein. Clin Res 1988; 36 : A503.

35. Subramaniam S, Srinivasan S, Bummer PM, Gairola CG. Perinatal sidestream cigarette smoke exposure and the developing pulmonary surfactant system in rats. Hum Exp Toxicol 1999; 18: 206-211.

36. Subramaniam S, Whitsett JA, Hull W, Gairola CG. Alteration of pulmonary surfactant proteins in rats chronically exposed to cigarette smoke. Toxicol Appl Pharmacol 1996; 140: 274-280.

37. Li XY, Rohman I, Donaldson K, MacNee W. Mechanisms of cigarette smoke induced increased airspace permeability. Thorax 1996; 51: 464 471.

38. Nilsson K, Evander E, Wollmer P. Pulmonary clearance of [99mTc]DTPA and [99mTc]albumin in smokers. Clin Physiol 1997; 17: 183-192.

39. Smith GB, Gastonguay A, Donnelly PJ, Reid KR, Petsikas D, Massey TE. Biotransformation of the tobacco-specific carcinogen 4-(methylnitrosamine)-1(-3-pyridine)-1-butadone (NNK) in freshly isolated human lung cells. Carcinogenesis 1999; 20: 1809-1818.

40. Lee KW, Chung SY, Yang I, Lee Y, Ko EY, Park MJ. Correlation of aging and smoking with air trapping at thin-section CT of the lung in asymptomatic subjects. Radiology 2000; 214: 831-836.
41. Soejima K, Yamaguchi K, Kohda E, et al. Longitudinal follow-up study of smoking-induced lung density changes by high-resolution computed tomography. Am J Respir Crit Care Med 2000; 161: 1264 1273.

42. Zeman KL, Bennett WD. Measuring alveolar dimensions at total lung capacity by aerosol-derived airway morphometry. J Aerosol Med 1995; 8: 135-147.

43. Lai-Fook SJ, Hyatt RE. Effects of age on elastic moduli of human lungs. J Appl Physiol 2000; 89: 163-168.

44. Foster JA, Curtiss SW. The regulation of lung elastin synthesis. Am J Physiol 1990; 259: L13-L23.

45. Thurlbeck WM. Internal surface area and other measurements in emphysema. Thorax 1967; 22: 483-496.

46. Robert CM, Cairns D, Bryant DH, Burke WM, Yeates M, Blake H. Changes in epithelial lining fluid albumin associated with smoking and interstitial lung disease. Eur Respir J 1993; 6: 110-115.

47. Jensen SM, Jones JE, Pass H, Steinberg SM, Linnoila RI. Clara cell $10 \mathrm{kDa}$ protein mRNA in normal and atypical regions of human respiratory epithelium. Int $J$ Cancer 1994; 58: 629-637.

48. Hanley K, Rassner U, Jiang Y, Vansomphone D, Crumrine D, Komuves L. Hormonal basis for the gender difference in epidermal barrier formation in the fetal rat. Acceleration by estrogen and delay by testosterone. J Clin Invest 1996; 97: 2576-2584.

49. Langhammer A, Johnsen R, Holmen J, Gulsvik A, Bjermer L. Cigarette smoking gives more respiratory symptoms among women than among men. The Nord-Trødelag Health Study (HUNT). J Epidemiol Community Health 2000; 54: 917-922.

50. American Thoracic Society. Lung function testing: selection of reference values and interpretative strategies. Am Rev Respir Dis 1991; 144: 1202-1218.

51. Thurlbeck WM. Postnatal human lung growth. Thorax 1982; 37: 564-571. 